\title{
Chapter 6 \\ Mass Housing and Extensive Urbanism in the Baltic Countries and Central/ \\ Eastern Europe: A Comparative Overview
}

\section{Miles Glendinning}

\begin{abstract}
This chapter provides a comparative overview of the post-war housing programmes of the Central and Eastern European post-war socialist states, arguing that they, like the Baltics, were in some ways distanced from the highly standardised orthodoxies of mainstream Soviet mass housing. With the aim of underlining the extreme diversity of the political/organisational and architectural solutions of mass housing within Central and Eastern Europe, the chapter demonstrates that while public housing was generally dominant in most parts of the region, this concealed wide variations, from the programmes of Poland and East Germany, dominated from the late 50 s by large, powerful cooperatives, to the highly decentralised, even anarchic system in Yugoslavia and the prominence of home-ownership in both Hungary and Bulgaria. Architecturally, the conservative policies of street-façade monumental architecture that prevailed in Ceaușescu's Romania contrasted very strikingly with the idiosyncrasies that sprouted elsewhere, ranging from the sinuous and extraordinarily long 'falowiec' (wave-form) blocks of Gdańsk and Poznań to the wildly variegated design solutions of the various 'blok' sections of Novi Beograd. The chapter compares these varied patterns closely with those of the Baltics, to demonstrate that the latter were not alone within the socialist bloc in their individuality and intermittently 'western' sensibilities.
\end{abstract}

Keywords Prefabrication - Mass housing $\cdot$ Multi-storey flats $\cdot$ Modernism • City planning

M. Glendinning $(\bowtie)$

Scottish Centre for Conservation Studies, University of Edinburgh, Edinburgh, Scotland e-mail: m.glendinning@ed.ac.uk

(C) The Author(s) 2019

D. B. Hess and T. Tammaru (eds.), Housing Estates in the Baltic Countries,

The Urban Book Series, https://doi.org/10.1007/978-3-030-23392-1_6 


\subsection{Mass Housing in the Baltics and the USSR: A Contextual Overview}

This chapter provides a comparative overview of the post-war housing programmes of the Central and Eastern European post-war socialist states, aiming to create a context against which to judge the claims of the special, uniquely 'westward looking architecture' of 'Baltic modernism' (to quote the title of Marija Dremaitè's recent book) (Drèmaitè 2017: 313-5). The recent work by Philipp Meuser and other writers in researching the standard designs, and design discourses, within the Soviet Union has helped dispel the notion that these type-plans were a matter of shoddy homogeneity, and has highlighted the place-specific character of housing in Soviet cities and regions, including Tashkent and Leningrad as well as the Baltic republics. (Meuser 2015) To complement this, my chapter will focus on socialist Central and Eastern Europe, with the aim of underlining the extreme diversity of the political/ organisational and architectural solutions of mass housing within the region.

What were the characterising features of mass housing in the Baltics as opposed to the predominant patterns in the USSR as a whole? With the latter, four broad defining aspects can be pointed to, albeit with considerable simplification: first, the strong, indeed binary polarisation of the organisation of housing between departmental (vedomstvenni) and municipal (Soviet) housing provision, with both private and cooperative housing tolerated only intermittently. Second, the concept of a grand, all-embracing hierarchy of planning, from the union level right down to the individual urban community unit (mikrorayon) and, ultimately individual apartment block, and including the 'urban' development of collectivised rural settlements. Thirdly, stemming from the plentiful supply of state-owned land, an approach to urban design, dubbed 'extensive urbanism' ('extensive Stadtentwicklung') that combined modernist mikrorayon planning with a vast spaciousness and grand 'magistrale' road layouts; and fourthly, under the post-1953 reaction against Stalinism, an intense focus on housing standardisation, type planning and mass production (spearheaded by the renowned ' $\mathrm{SNiP}$ ', or 'housing norms and regulations'), and prefabricated concrete panel construction (Bernhardt 2005).

The Baltic states shared much of this system, but with significant divergences. Organisationally, the forcible character of the Soviet takeover resulted in an unusually high percentage of public housing held by local Soviets as opposed to state enterprises, and-ironically, in view of the long-standing traditions of individual family houses in the Baltics - an unusually low proportion of private housing (Kalm 2002). Architecturally, the relatively short-lived ascendancy of Stalinist Socialist Realism and the persistence of nationalist sentiments ensured that the post-war years saw escalating attempts to offset Soviet extensive urbanism with a 'regional' approach to architectural design, including 'folk' or 'vernacular' sub-trends - although the latter were by no means confined to the Baltic republics, but emerged in an even more emphatic manner in the mass housing of Tashkent and of Central Asia. More generally, designers in the Baltics, as 'the little Soviet West', outdid those of other republics in their eager embrace of the growing cultural and 
architectural exchanges with Western countries from the late 1950s onwards, especially Finland and the rest of Scandinavia (Drèmaite 2017: 76). Yet the Baltics also reflected the centralising aspects of the Soviet system of standardisation, including $\mathrm{SNiP}$ or the definition of housing space in terms not of numbers of dwellings or rooms but of aggregate 'living space' ('zhilaia ploshchad'). In Estonia, for example, local variants of key Soviet types were faithfully developed, beginning in 1956 with design institute Estonprojekt's I-317 adaptation of the standard khrushchëvka, by Mart Port and others (Ojari 2004); and the principles of extensive urbanism were reflected in the concentration of the housing drive in Tallinn into three mega-projects, Mustamäe, Väike-Õismäe and Lasnamäe, roughly corresponding to the 1960s, 70s and 80s.

Central and Eastern Europe, as we will see in this chapter, echoed the divergences and exceptionalism of the Baltic republics' housing in an even more exaggerated way, not least through their very diversity of socialist tenures and architectural design. For example, alongside the sharp Soviet departmental/Soviet split, other tenures were equally prominent, including housing associations, cooperatives, private construction and the famous Yugoslav 'self-managing communities of interest'. Within planning and the built environment, there was a prominent use of prefabricated concrete construction and standardised building types, as in the Baltics and the rest of the USSR, but, in general, on a less overpowering scale; in general, new housing developments were normally related to existing urban fabrics (Zarecor 2017: 9). Overall, the affinity between the core satellites of the USSREast Germany, Poland, Czechoslovakia, Bulgaria, Hungary-was especially strong, while Romania and Yugoslavia followed a much more idiosyncratic pattern.

\subsection{The Satellite States: From Dissidence to Decomposition}

At the centre of the Soviet satellite system was the group of states which remained under Soviet domination from World War II right up until 1989: East Germany (the German Democratic Republic, or GDR), Poland, Hungary, Czechoslovakia and Bulgaria. Overall, these states shared the Soviet system's typical organisational features, of central planning, oral decision-making culture, secrecy and concern with propaganda - a system within which the environment, including mass housing, was both an outcome and a source of state power- as evinced in the elaborate propaganda exploitation of housing 'spectacles' and 'milestones', such as the close interlinking of the completion and naming of Budapest's prestige Havanna development with the 1978 World Federation of Democratic students Congress in Cuba (Urban 2009: 5, 49, 259). These nations also, however, mostly shared a common background of susceptibility to popular unrest against Soviet hegemony, leaving mass housing output drives very often filling a palliative role in the wake of 
unsuccessful uprisings or political liberalisations-for example in post-1956 Hungary. (Ferkai 2005: 56-8; Campbell and Hall 2015: 23).

In central Europe, long-established traditions of municipal power and authority, very different to the Russian situation, also often obstructed the onward march of 'democratic centralism' - for example in Hungary, where the post-war creation of a regional 'Greater Budapest' and the intervention of numerous Soviet-style ministries and industries drastically curbed the housing powers of Budapest's City Council; or even in the GDR, where local authorities retained some significant planning and housing authority, especially in the large cities targeted for planned growth from the 1950s onwards (Molnár 2013: 45-58; Bernhardt 2005: 104-119; Bernhardt and Reif 2009). In some of the more rural countries in the region, such as Bulgaria, there was very little prior history of communism, and low-density, single-storey village type housing was prominent, whereas the GDR and Czechoslovakia featured a strong and entrenched urban proletariat. These disparities in the degree of backwardness in urban development were reflected in sharp differences in the scope of modernising reconstruction, but all the satellite states showed, in principle, a common ethos of universalism within social and economic policy, avoiding sharp differences of private and public or collective life. (Hannemann 1996: 111; Sillince 1990: 477-82)

How, then, was the specific provision of mass housing organised within this at times uncertain bloc of state socialist countries? Overall, as in the USSR, a pyramidal hierarchy, operating through command planning, prevailed. But tenurially speaking, there was significant variety. Despite the general stress on planned industry in all satellite bloc countries, the relative importance of enterprise housing varied widely; municipal authorities played an especially strong role in Hungary, Poland and Czechoslovakia. Overall, however, there was a rather early shift away from standard Soviet tenurial solutions in the region, with many countries shifting sharply away from direct state production altogether, as early as the 1970s in Hungary and Bulgaria and following in the 1980s in Czechoslovakia and Poland. The two overwhelming beneficiaries of the swing away from state command production were the cooperatives, and outright private building. In Poland, the shift to co-op building began especially early and grew rapidly: they were initially boosted under Władysław Gomułka from 1956, reaching 22\% of total output by 1961-5 and subsequently higher still (Donnison 1965: 91-3, 109; Sillince 1990: 62-77, 173, 477-82; Tsenkova 2009: 42; Wynn 1984: 236). Unlike their precarious role in the USSR, including the Baltics, co-ops in Poland operated in effect as local agencies of the state and frequently built on a very large scale, both quantitatively and architecturally, with land allocations guaranteed by the central government social housing agency, the Construction Directorate of Workers' Estates. (Marmot 1981: 180; Rietdorf 1976: 146). In the GDR, a very similar socialist co-op system got seriously underway early, as a response to the 1953 popular uprisings, whereas in Czechoslovakia, Hungary and Bulgaria, the big shift to co-ops came slightly later, in Czechoslovakia in 1958-9 with a $40 \%$ state subsidy, and in Bulgaria from the 
mid-1960s, as part of a radical expansion of state-sponsored house building from $20 \%$ of all new housing in 1961-5 to 50\% in 1977 (Sillince 1990: 37-9, 90-04, 183, 330-43, 475; Deutsche Bauakademie 1968: 9-14; Jordan March 1967a; Jordan April 1967b; Balchin 1996: 245-51, 272-6).

As in the case of the USSR, outright private enterprise building played a surprisingly large role in the housing production of the socialist countries, but here steadily increasing, rather than reducing, in importance-with the aid of long-term loans from the state (Tsenkova 2009: 42-4). There was, however, a significant division between countries where the subsidised private sector was dominated by individual detached houses in villages and country towns, as in Poland or Bulgaria, and those where it was integrated with the urban flat building programme. Hungary strongly emphasised the latter during the post-1956 years of 'goulash communism' under the liberal János Kádár regime, culminating in large-scale 1970s multi-storey Budapest developments such as Havanna (1978), where $30 \%$ of the flats were owner-occupied from the start. To some extent, given the strongly universalistic and totalitarian character of the system, arguably more important than details of tenure was the overall level of state-sponsored production, with its sharp differences in peaks and troughs. Here the two chief alternatives were an early production peak in the 1960s and early 1970s, and a later peak in the 70s and 80s. The former was exemplified by Hungary, where the determined attempts in the post-1956 period to win the loyalty of better-off workers via a 15-year, 1961-75 mass programme (Rietdorf 1976: 76; Ferkai 2005: 56-8; Sillince 1990: 39, 66, 90-104, 459-82; Balchin 1996: 245-51). In the GDR, by contrast, the housing programme continued building up almost to the end of socialist rule in 1989, with a per capita maximum far above that of the other satellite states, and achieved 10 years later than them. This was largely the personal achievement of Erich Honecker, appointed SED party leader in 1971, who immediately launched a vast building drive, codified in 19735 , and revolving around a system of 'complex housing construction', under which the state planning commission set central housing targets for execution on an agency basis by local governments (Volkseigene) and cooperatives on sites centrally allocated by the Bezirke, or administrative provinces. The achievements of this programme were celebrated and exaggerated in highly choreographed spectacle events - the supposed 'millionth', 'two-millionth' and 'three-millionth' dwelling completions. (Wynn 1984: 220-47; Sillince 1990: 337; Angermann and Hilse 2014: 117-8; Honecker 1981: 302-16; Urban 2009: 256-9; Fiedler and Georgen 2008: 40; Rietdorf 1976: 106).

\subsection{Housing Architecture in the Satellite States}

Architecturally, the satellite states relatively closely echoed Soviet patterns, in a way that differed sharply from the US-Western European relationship, albeit with a considerable diversity of interpretation, that reflected the ideology of 'socialist 
competition' and echoed the official rhetoric of unified planning, design and building. This system was restrainedly celebrated in Werner Rietdorf's illustrated overview book of 1975, which picked out Hungary as 'exemplary' in design consistency (Bernhardt and Reif 2009; Marmot 1981). Although the Soviet fixation with living space was only more loosely reflected in these countries, with housing size more generally expressed in square metres per dwelling rather than per inhabitant, the overall assumption that the task was to build relatively basic shelter and small flats for very low rents, very often as part of wider building programmes of enterprises - was very similar to the Soviet Union (Donnison 1965). Common with the Baltics and the remainder of the Soviet Union, too, was the sharp late-1950s swing from Stalinist to post-Stalinist housing solutions, including the reliance on standardisation and industrialised building, and the planning emphasis on modernist 'extensive urbanism', mikrorayon layouts and avoidance of large-scale redevelopments (Bernhardt 2005: 111; Sillince 1990: 7).

The far shorter hegemony of Stalinism in these countries, however, guaranteed a subtly different chronological trajectory, within which the place of CIAM modernism was somewhat less problematic overall. In Czechoslovakia, Germany, and Hungary, 'Neues Bauen' architecture had put down deep roots at various points in the interwar years, and in all three countries, especially Czechoslovakia and Hungary, the years 1945-8 saw an initial blossoming of modernist experiments under a generally liberal left-wing umbrella, in fields as diverse as 'type' design, neighbourhood unit planning, and Existenzminimum small dwelling design. In the Baltics, by contrast, these years witnessed an immediate shift to Socialist Realism, especially in nomenklatura apartments, such as the stately four-storeyed classical ensemble designed in 1946 by Edgar Velbri for academics on Rävala Avenue, Tallinn, containing five-room apartments (and even servant quarters!) (Mumford 2009: 239-41; Zarecor 2011: 17-51; Gzell 1995; Lankots 2004) After a brief early 1950s ascendancy of Stalinist Socialist Realism, exemplified in projects such as the Stalinallee in Berlin or Nowa Huta in Poland, by 1955 the pendulum was swinging back again, reflecting Khrushchëv's denunciations of Stalinism in the USSR.

In this phase, the parallelism of developments in the Baltics and CEE was especially marked. From 1957, Soviet architects, including many from the Baltics, launched enthusiastically into visits to Finland and other Scandinavian countries, a particular focus of emulation being the Tapiola satellite town outside Helsinki; the neighbourhood-planning formulae of Scandinavia (and Britain) were also the focus of growing enthusiasm. The impact on the Baltics was both immediate and enduring. At the first of Tallinn's large prefabricated housing districts, Mustamäe, a 1958-9 competition-winning master plan by $\mathrm{T}$ Kallas, $\mathrm{M}$ Port and V Tippet employed an open-plan mikrorayon layout for the first time in Estonia. As built (1962-73), Mustamäe was dominated by five-storey khrushchëvki, arranged in nine mikrorayons, and including one explicitly 'Scandinavian' feature: the so-called ABC mikrorayon centres, inspired by the 1950s Swedish 'Arbete-Bostad-Centrum' centres, such as Vällingby. (Metspalu and Hess 2018; Lankots and Söövati 2008). The Baltic 'aura' of the new Scandinavian connection continued throughout the 1960s and early 70s, notably in the Vilnius district of Lazdynai, 1962-73, laid out 
by two ambitious young architects, Vytautas Brėdikis and Vytautas Čekanauskas, as the first of a series of peripheral developments. Standard 5, 9 and 12 storey blocks (series 'I-461-LI') were picturesquely disposed on a wooded site in four mikrorayons - three of which, unusually, were provided with well-equipped centres from the outset (Drèmaite 2017: 168-179). Similarly, German, Polish and Czechoslovak housing architects looked to Scandinavia and Britain for new-town and community planning, while embracing the cause of industrialised building and assiduously visiting prefabricated developments in Sweden, Denmark and France (Hannemann 1996: 58; Bernhardt 2005: 115; Topfstedt 1996; Dufaux and Fourcault 2004: 103-5; Gzell 1995). In Hungary, the turmoil of 1956 obstructed any immediate architectural 'thaw', and it was only slightly later, around 1958, that the first attempts were made to lay the ground for fully fledged modernism in Hungarian housing, above all in the Óbuda experimental development in Budapest, a domestic echo of the 1957 Berlin Interbau and Scandinavian precedents in its intended role as a prototype for modernist community planning, housing architecture and interior furniture and fittings (Molnár 2013: 78, 117; Branczik and Keller 2011; Branczik 2012).

In Eastern Europe, the post-war urbanist conceptions of modern housing naturally echoed the Soviet formula of 'extensive urbanism', albeit in a somewhat smaller scale and more diluted form - as documented, for example, in Rietdorf's book (whose front cover illustrates Lazdynai) (Rietdorf 1976: 260-71; Zarecor 2011). Although also reflecting Scandinavian and British neighbourhood-unit planning, the Eastern European version of extensive urbanism was also close to the French grand ensemble concept (Molnár 2013: 45-58; Hannemann 1996: 67; Moravčíková et al. 2011). In almost all cases, this approach was linked integrally to industrialised building, and, just as with Mustamäe in Estonia, the first really large-scale development in any country was often also its first large industrialised building development: for example, Kelenföld in Budapest or Hoyerswerda in the GDR, the latter anticipating a succession of East German Grosssiedlungen, such as Erfurt-Nord, Karl Marx Stadt, Rostock or Berlin-Marzahn (Architects' Journal March 1967; Ferkai 2005: 64-7; Hannemann 2004; Rietdorf 1976: 120; Bernhardt 2005). Correspondingly, there was a marked reluctance to demolish existing housing stock - in contrast to the vast 'slum-clearance' projects of Britain and the USA. This reluctance was fully shared by the Baltics, where, for instance, a succession of grandiose rebuilding plans for the decayed Tartu inner-suburb of Supilinn remained unrealised, even as the giant new Annelinn housing zone was developed on the city's south-east edge. As Tallinn's City Architect (1960-80), Dmitri Bruns, recalled, 'big complexes like Mustamäe were built on virgin land because the housing crisis was so deep that redevelopment was out of the question' (Hess and Hiob 2014; interview with Dmitri Bruns by MG 29-5-2011).

At what level of scale the building of grands ensembles shaded into the building of entire new towns or even satellite towns is unclear, whichever period we look at: but normally the key factor was the involvement of a large-scale enterprise: the first projects of very large-scale developments were already underway in the Socialist Realist period in the early 50s as in the case of Nowa Huta or Stalinstadt; but it was 
only after the shift from Socialist Realism to extensive urbanism in the late 50s, and the move to industrialised building, that the scale of development really ramped up - a movement in which the Baltic states participated only on a modest scale, for example in Lithuania with new towns such as the 4,000-inhabitant Elektrènai, built for power-plant workers in the 1960s with a housing stock of prefabricated slabs, and Sniečkus, a forest new-town for nuclear power station workers, built in 1975-89 on a grandiose, butterfly-plan three-mikrorayon layout. (Drėmaite 2017: 109-115) In many CEE cases, the 'new towns' were not completely new, but, rather, massive and semiautonomous satellites dwarfing existing settlements, as in the case of Halle-Neustadt, where a completely autonomous 'Stadt der Chemiearbeiter' was constructed beside the existing 'Altstadt', with the full panoply of Extensive Urbanist planning (Fig. 6.1), including a main magistrale and serried lines of towers (Hannemann 1996: 64; Hannemann 2004; Topfstedt 1996: 44; Angermann and Hilse 2014: 97-8; Diener 2012; Rietdorf 1976: 120-1).

Most CEE states had no comprehensive equivalent to the USSR's modernist 'rural urbanisation' strategy, within which the Baltics played a leading role, through showpiece collective farms, bristling with apartment blocks and public buildings, sometimes designed in a highly individualistic manner that contrasted with the standardisation of urban housing. For example, at Juknaičiai, Lithuania, the Central Settlement of the 25th CPSU Congress Soviet Farm was developed from 1964 under the forceful chairmanship of Zigmas Dokšas as a highly landscaped

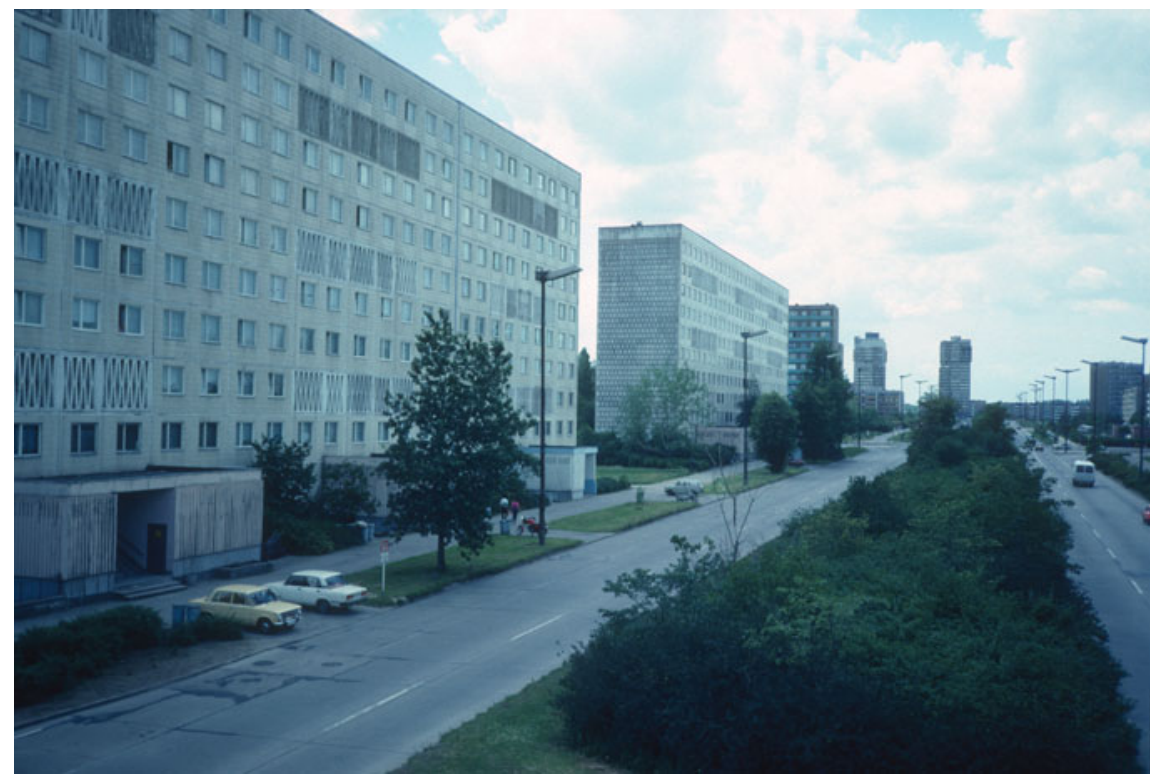

Fig. 6.1 Chemiearbeiterstadt Halle-Neustadt, East Germany: a GDR showpiece of Extensive Urbanism. This view shows Wohnkomplex I, comprising 5233 flats built in 1964-8 Source M Glendinning, 1990 
showpiece, with apartment blocks with exaggerated gabled roofs, and lavish central institutions (Drèmaitė 2017: 136-145). Likewise, in Estonia, farm centres were developed in the form of urban complexes featuring arrays of parallel three- to four-storey prefabricated apartment blocks - for instance in a 1970s plan by architect Valve Pormeister for the central settlement of the Kurtna experimental poultry farm (Kalm 2008; Topfstedt 1996; Rietdorf 1976: 112-25; Deutsche Bauakademie 1968: 281-93; Drèmaitė 2017: 138).

In Eastern Europe as in the Soviet Union, the drive for industrialised building was integrated into the drive for 'extensive urbanism', but the impulse towards large load-bearing panel industrialisation was nowhere quite as single-minded as the Soviet Union - with the arguable exception of East Germany during the Honecker 'dash for numbers' in the 70s and 80s. Despite post-1957 efforts at inter-state coordination under the aegis of the CMEA (Comecon), what was almost entirely absent in the satellite states was a direct equivalent to the massive, early Soviet boom in prefabricated building during the Khrushchëv years, especially in 1957-60. In Czechoslovakia, to be sure, the first experimental 'panelaks' began to appear in Prague, Bratislava and elsewhere from 1956, with later, experimental industrialised schemes such as an aluminium-panel-clad slab block at Invalidovna in Prague; and in East Germany, large-scale production got seriously underway with the founding of the first Baukombinaten and the 1957 commencement of Hoyerswerda, trumpeted as 'the first industrially built town in the GDR'. (Donnison 1965: 110; Zarecor 2011: 289-93; Moravčíková et al. 2011: 20-3, 46-9; Jordan April 1967b; Pugh 2015) But in general, the shift to industrialised building was generally more belated than in the USSR. Hungary, with its strong emphasis on single family owner-occupied housing, began prefabricated construction only in 1961 but thereafter rapidly accelerating, with four house building combines and concrete factories inaugurated in the 1960s, including three built with Soviet help by 1965 , and one built as a joint venture with Larsen \& Nielsen in 1968: the first major prefabricated development, Kelenföld, used a Soviet system (Fig. 6.2). In East Germany, while the ideological facade of Honecker's campaign was provided by the much showcased 'million' milestones, its technical kernel was an East German variant on the Soviet quest for unified systems: the WBS (Wohnbauserie) 70, which tried to simplify the range of types that had proliferated since Hoyerswerda into a single 'family' (Fig. 6.3) (Sebestyén 1965; Molnár 2013: 79; Ferkai 2005: 65-66; Architects' Journal March 1967: 713-715; Angermann and Hilse 2014: 91; Hannemann 1996: 82-92; Hannemann 2004; Wynn 1984: 220246; Rietdorf 1976: 106, 252-4).

\subsection{Divergences from Orthodox Modernism}

No sooner was the industrialised building campaign fully established, in the mid-1960s, then a growing clamour began, especially along architects such as Bruno Flierl in the GDR, against its supposed 'monotony'. These criticisms came 


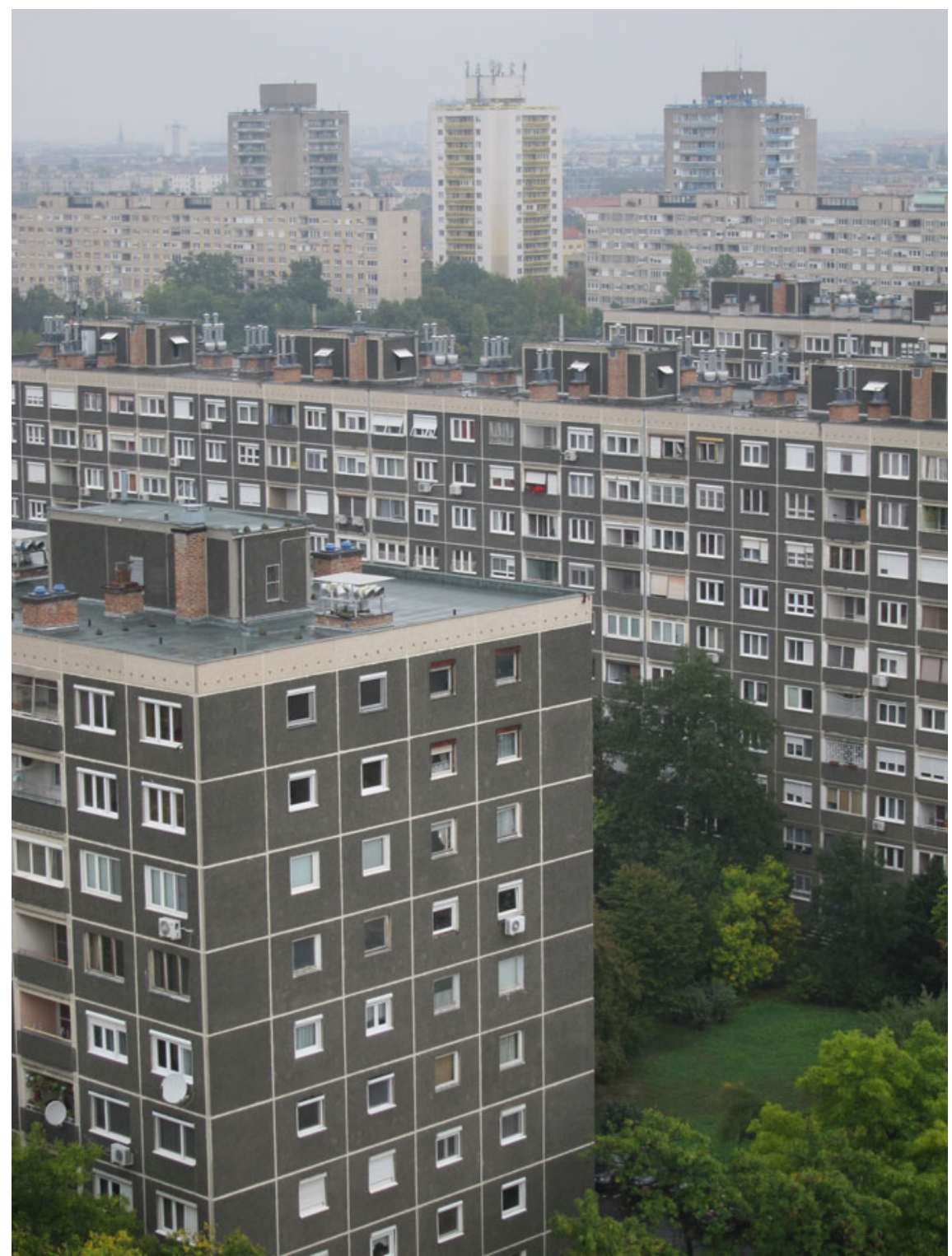

Fig. 6.2 Kelenföld, Budapest: pioneering prefabricated blocks built from 1965 using a Soviet spin-off of the Camus system Source M Glendinning, 2015 


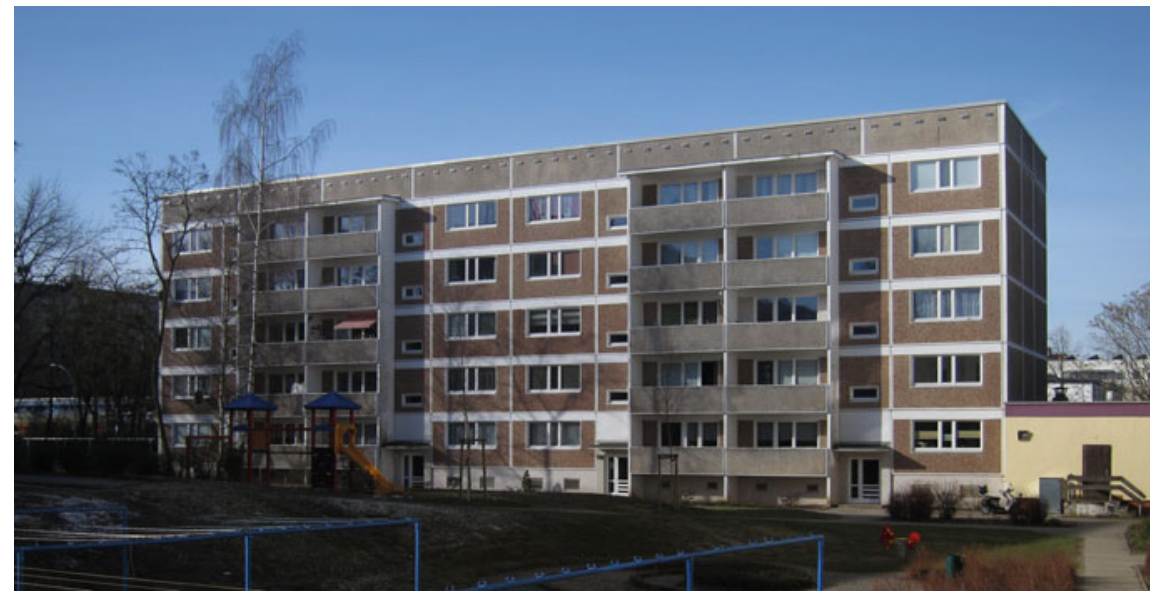

Fig. 6.3 Koszaliner Str. 1-7, Neubrandenburg, East Germany: the first built example of the GDR's WBS 70 standard large-panel prefabricated concrete series, constructed in 1973 (and designated a heritage monument in 1984) Source M Glendinning, 2017

somewhat earlier than their equivalents in the Baltics and the rest of the Soviet Union. In Tallinn, for instance, the late $70 \mathrm{~s}$ saw growing newspaper criticisms of the unfinished state of Väike-Õismäe, and by the late-1980s a fully fledged polemical campaign of 'Stop Lasnamäe!' was underway (Urban 2011: 68-71; Pugh 2015: 87-101; Moravčíková et al. 2011: 54-57; Metspalu and Hess 2018: 17-18). One of the favourite remedies for standardised 'monotony' advocated by late Soviet designers was to promote 'experimental', non-standard projects, partly exempted from the exigencies of SNiP, including 'monolithic' tower blocks built in in situ rather than large-panel concrete, with more flexible plans and individualistic 'sculptural' profiles. Here Lithuania played a leading role, in the 1980 s 'monolitas' programme in Vilnius, whose earliest examples were the towers that studded the skyline of Lazdynai from 1980, designed by architect Česlovas Mazūras (Drèmaitè 2017: 185-9).

In the CEE countries, the architectural responses to the criticisms of orthodox modernism were often somewhat more exaggerated than those in the Baltics, or the rest of the Soviet Union for that matter. One common response was a shift to more 'urban' and dense forms, and more flexible, conglomerate-like planning-for example, in Budapest's Újpalota (1970-5), with its linear arrangement along two colliding planes, with a landmark tower at the intersection. Beyond these, a limited range of more utopian initiatives proposed more extreme solutions, whether megastructural, as in the vast linear 'Strip' development advocated in Budapest by Elemér Zalotay, or the projects of Oskar Hansen in Poland, which combined innovative high density forms with attempts at participatory social input (Ferkai 2005: 67-71; Hryniewicz-Lamber 2004; Molnár 2013: 92; Branczik 2012: 190-191; Kedziorek and Stanek 2012). Although Zalotay's Strip was never 
constructed, from the mid-1960s a group of Polish designers actually built something not far removed from it in scale, in the form of the 'Falowiec' (Wave) projects - enormously long 11 or 12 storey slab blocks of a very unusual, undulating ground plan and featuring balcony rather than the more usual Soviet-style 'sectional' staircase plan. The main group of Falowiec blocks was in the northern suburbs of Gdańsk, in the Przymorze development, built by a single, giant cooperative, the PSM Przymorze (Fig. 6.4). The Falowiec sector of Przymorze, begun in 1964, was put out to competition, with winner Stanisław Różański acting as project design leader within the Gdańsk city design collective, 'Miastoprojekt': 1966-7 saw construction of the first two Falowiec blocks, while the culmination was an immense 'kolos' (colossus) of 16 sections and over $800 \mathrm{~m}$ length (1970-3). The only Baltic equivalent to these vast, curved forms in the landscape is the huge circle of Tallinn's Väike-Õismäe, with its flanking 5 and 9 storey slabs and landmark clumps of 16-storey towers-a 38,000-inhabitant development planned from 1968 by Mart Port, with Malle Meelak, and built 1972-6; but its 'macro-rayon' plan was far more regular in character (Interviews of Dmitri Bruns and Mart Port by MG, 29 May 2011).

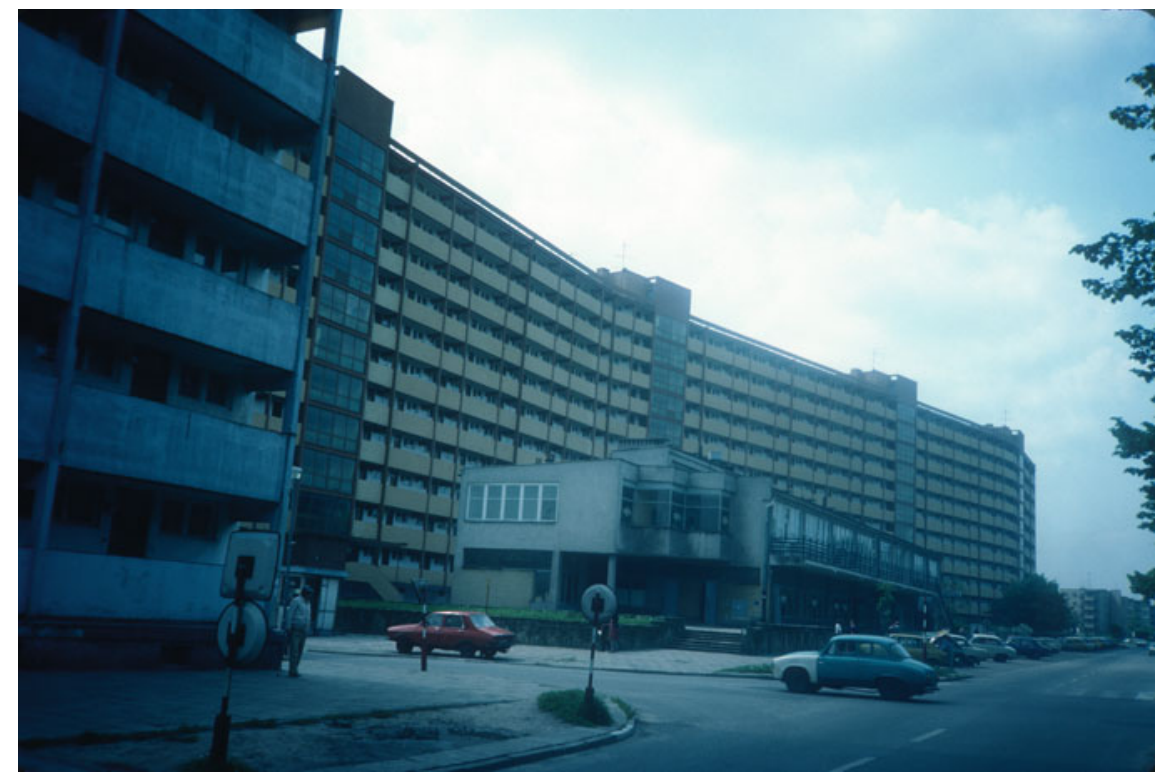

Fig. 6.4 Ul. Piastkowska, Przymorze, Gdańsk, Poland: 11-storey 'Falowiec' slab block built in 1966-7 by the PSM Przymorze cooperative (designers, Miastoprojekt city design collective) Source M Glendinning, 1983 
In historic urban settings, a calculatedly 'contextual' approach had been developed in many places long before that point, with some roots in Stalinist Socialist Realism. With the general post-

Stalinist switch to modernist architecture and planning, slightly different approaches to housing reconstruction of war-devastated, ex-German, Polish cities were attempted, as in the case of Wrocław's Nowy Targ, where a complex succession of plans and proposals was followed by a 'conditional reconstruction' (from 1956), employing modernist blocks of roughly the same scale as the previous buildings, and laid out in a combination of street, courtyard and modern open-plan layouts (www.smpiast.pl/ospoldzielni.html; Friedrich 2010). In East Germany, contextual variants of the WBS 70 were designed for specific locations-a programme not matched anywhere in the USSR, even in the Baltic states, where inner-city projects generally used slab blocks similar to the peripheral estates (Fig. 6.5) (Sillince 1990: 4-7, 114-9; Urban 2009; Angermann and Hilse 2014: 2123, 38-56, 97-8; Deutsche Bauakademie 1968: 284-291).

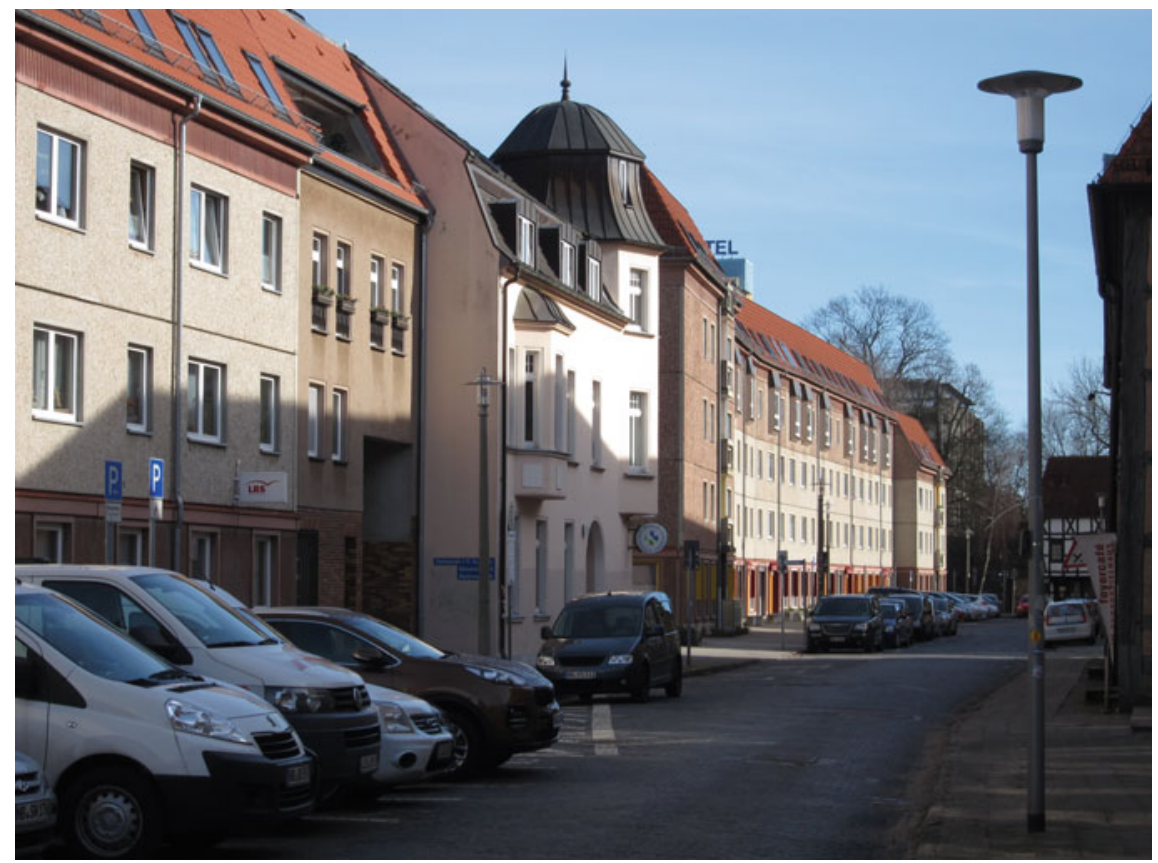

Fig. 6.5 Pfaffenstrasse, Neubrandenburg: 'contextual' WBS 70 Plattenbau developments of the mid-1980s in an Altstadt setting Source M Glendinning, 2017 


\subsection{Socialist Exceptions: Mass Housing in Romania and Yugoslavia}

Whereas the satellite bloc countries all followed relatively similar policies and architectural patterns, and attempted to reflect Soviet precedent in one way or another, in Romania and Yugoslavia, completely different, and wildly diverse, patterns prevailed. (Sillince 1990: 360-386)

In Romania, the overall trajectory of housing production, especially in the late socialist years, was towards ever greater state centralisation and 'systematisation', whereas in Yugoslavia, the mass housing programme was shaped by an escalating national ethos of decentralisation and incessant reorganisation, amounting eventually almost to anarchy. In the 1940s Romania, rather like Bulgaria, was an overwhelmingly agrarian society with almost no 'communist proletariat'. In response, a very tight Stalinist control was established from the beginning by communist leader (1944-65) Gheorghe Gheorghiu-Dei, combined with a strategy of rapid forced urbanisation and population growth, combined with conservation of agricultural land. But this was combined with a growing estrangement from Moscow, beginning in 1952 and deepening during the Khrushchëv 'thaw', which he combated with a recipe of socialist nationalism, announcing in 1964 the 'calea romaneasca spre comunism'. After Gheorghiu's death in 1965, Nicolae Ceauşescu gradually emerged as leader, being recognised by the 1970s as 'conducator' and promoting an ideology of 'comunismului national' (Zahariade 2011: 14-25, 40-44; Rietdorf 1976: 182).

In both the organisation and architecture of mass housing, Romania underwent a succession of fluctuations that set it strikingly apart from every other socialist regime. State expenditure was overwhelmingly focused on industry, with housing seen as a low priority. In the immediate post-war years, there was a strong emphasis on the building of private housing. However, by the late 1980s, in stark contrast to neighbouring Hungary, private building in Romania had dropped to almost nil. Architecturally, Romania was unusual in experiencing a rather shorter ascendancy of orthodox international modernism, with socialist realism only really abating from around 1958-9, and a distinctive Romanian counter-reaction against modern urban planning already underway by 1966 . The initially very low early post-war pace of apartment building quickened rapidly from around 1957. Here, a penchant for the monumentality of grand magistrales and squares remained unusually prominent (Sillince 1990: 135-152; Rietdorf 1976: 185-189; Tsenkova 2009: 39-42; Zahariade 2011: 45-48). Even at the height of straightforward modernism in Romania, in the late 50s and early 60s, spectacle-building along great boulevards was ubiquitous. In some cases these built on existing ensembles, such as Bucharest's Grivița project of 1958-65, including the classical Piaţa Gării de Nord, while others were quite new, such as Piaţa 3 Decembrie, with its cluster of monumental buildings at a busy street junction; by 1969, the Cartierul Floreasca featured a kvartal layout with densely filled street blocks (Sillince 1990: 150; Laurian 1965: 364; Ionescu, et al. 1969; Zahariade 2011: 30-36, 49). 
In much the same way that Soviet planning was based on a totalising, hierarchical concept for the national territory as a whole, including rural as well as peri-urban development, its Romanian counterpart, 'systematisation' (sistematizare), did much the same - uniquely in the CEE states - but with very different built results. As early as the early 1950s, the term was already being bandied about in debates about the planning of Bucharest, within which it meant little more than methodical spatial planning, but it was only following a 1966 speech by Ceauşescu, in which he called for greater economy and land use and for efforts to diversify housing to avoid monotony, that systematisation began to take on specific, and increasingly idiosyncratic, architectural form. Just as Khrushchëv had denounced Socialist Realism as wasteful in the mid-50s, so Ceauşescu's critique focused on the damaging effects of waste-only, in this case, of land, rather than building resources. He vigorously condemned modern functionalist grands ensembles as both profligate of land and architecturally monotonous. Reflecting these critiques, national planners drew up a systematisation programme in 1972, and a general systematisation law followed in 1974, synthesising all previous acts. This was to be a total national strategy of urban concentration, curbing urban peripheral sprawl and reorganising rural villages, with some picked out for modern planned development and others for abandonment and, even, demolition. Within the cities, a 1975 'streets law' mandated that open-plan modernist street layouts should be infilled with additional blocks, and new developments were designed in open street-block layouts incorporating curved, segmental or chamfered elements. In 1985, Ceaușescu proclaimed that within five years, $90-95 \%$ of the inhabitants of Bucharest would live in apartments, and increasing efforts began to clear away 'wasteful' low-density parts of the capital, and substitute taller, standard type blocks (Zahariade 2011: 3662; Tsenkova 2009: 39; Sillince 1990: 135-152; Ciolacu 2015; Marin 2011).

\subsection{The 'Ongoing Revolution': Self-management and Monumentality in Yugoslavia}

Like Romania, Yugoslav policy was dominated by a determination to promote equalisation of disparities across the whole country-but in almost all other respects, its post-war planning and housing policies could hardly have been more different (Mrduljaš and Kulić 2012: 6-10). Tito's Yugoslavia combined a highly assertive external self-projection as a redoubt of nonalignment with a multinational internal structure and a dominant, all-pervasive organisational discourse of incessant, decentralising reorganisation and its architectural outcomes were among the most spectacular and individualistic in post-war Europe-eclipsing even the most flamboyant Soviet efforts, Baltics included.

In geopolitical and economic terms, post-war Yugoslavia experienced around 35 years of relative strength and prosperity, framed by years of crisis and impoverishment. Politically and architecturally, Yugoslavia differed radically from its 
neighbours, not only in its strongly multinational, and multi-ethnic character, but in the idiosyncratic interpretation of socialism favoured by Tito and the Yugoslav leadership. They took to an extreme the Marxist and Leninist concept of the 'withering away of the state', as a prescription for radical devolution of power within society to ever more complex participatory structures, combined with constant constitutional reorganisation, amounting to a 'revolucija koja teče' (ongoing revolution). Within this decentralised system, however, there were embedded highly centralised elements, above all the dominant figure of Tito himself; departmental enterprises also played a surprisingly prominent role in Tito's Yugoslavia, with organisations such as the Yugoslav National Army (JNA) or Jugoturbina able to act as 'first among equals' within the self-management system (Sillince 1990: 402; Mrduljaš and Kulić 2012: 18).

Yugoslavia's post-war housing history fell into three successive phases of increasingly radical devolution and complexity. The first phase comprised the early post-war years, up to 1952, when the country was battling with the economic hardships stemming from the break from Stalin and the Soviet economic embargo, and housing output only averaged around 5,000 per annum. During this time, the system was at its closest to the Soviet satellite bloc countries, but even then, the first moves towards decentralisation were under way. From 1956-7, centralised budget allocation was removed, and a 'social fund' was established, tasked with building rental housing financed by percentage contributions from all work organisations. (Wynn 1984: 156-160; Sillince 1990: 37, 402-4; Mrduljaš and Kulić 2012: 11-14, 406). The third phase of Yugoslav mass housing (1963-72) went further still in the direction both of the market and of decentralisation, abolishing the communal housing authorities and devolving responsibility for housing to commercially-funded 'self-managed enterprises'. In 1972, yet another housing reform enshrined the role of the 'self-managing community of interest' (samoupravna interesna zajednica), a category that included not only employee enterprise housing but a bewildering variety of community groups: by 1986 , over 600,000 people were involved in SIZ decision-making (Hegedüs et al. 2013: 130, 245; Tsenkova 2009: 40-42; ETH Studio Basel 2012: 187-8; Wynn 1984: 156-63; Architects' Journal April 1967: 997; Balchin 1996: 242-3; Sillince 1990: 402-28; Mrduljaš and Kulić 2012: 18-19, 188; Interviews by M Glendinning with D and M Marusić, and A Stjepanović, 7 July 2014).

In built-form terms, the complexity and fluctuations of the Yugoslav housing organisational system were reflected in an exceptionally variegated architectural landscape, resembling Western mass housing architecture more than the orderly, hierarchical mikroayons and rayons of the USSR, including all three of the Baltic States. In Yugoslavia, owing to the break with Russia, socialist realist housing had hardly any time to establish itself, and a reaffirmation of international modernism was signalled dramatically by the Zvezdara Hill project of 1953-5, with its cluster of slender, reinforced-concrete-frame towers, styled with 'winged' roofs-ostentatiously embracing western modernism just like designs such as Lazdynai, but a decade earlier. The building of idiosyncratically styled reinforced-concrete towers of ever greater scale continued to characterise Yugoslav cities in the 1960s and 70s 
- rather earlier than the monolithic Soviet craze exemplified by the sculptural monolith towers of Vilnius - but filling the same landmark role (Dremaite 2017: 185-9). Some were designs of extreme eccentricity, such as the Rudo (Eastern Gate) project in Belgrade, built 1967-76 as a spectacular group of three sail-like 28 storey towers arranged in a radiating triangular grouping, almost like a gigantic expo pavilion, designed by Vera Ćirković and others (Mitrović 1975: 19).

At a relatively early date, however, Yugoslav designers also embarked on a new design trend of medium-rise, conglomerate mega-developments, often on city outskirts, as, for example, at Split III - an approach for which there were few if any equivalents in the Baltic states. In some instances, massive towers were integrated into a dense, medium-rise base, as at the JNA-sponsored, megastructural Banjica development in South Belgrade (from 1966), designed by Mirjana Lukić. In strong contrast with the Soviet industrial prefabrication tradition, Yugoslav housing designers also developed a complex discourse of system building and prefabricated construction, orientated not towards mass systematisation but towards flexibility and open systems - exemplified by the 'IMS' system, developed from 1957 (Blagojević 2012: 3-4, 240; Mitrović 1975: 20-25; interviews D and M Marusić, 7 and 8 July 2014; Wynn 1984: 162-170; Architects' Journal April 1967; Mrduljaš and Kulić 2012: 175-188, 277-300, 410-416).

\subsection{Novi Beograd: Planning by 'Blok'}

Innovative and sometimes startling as these individual projects were, they were all overshadowed, within the Yugoslav planning and housing world, by the spectacular prestige, and architectural diversity, of Novi Beograd (New Belgrade) Yugoslavia's equivalent to Brasilia as a unifying new capital-first planned in 1948 but mostly stalled until 1956, Novi Beograd was very much the personal brainchild of Tito. Organisationally, a range of special central state and governmental enterprises was established to pursue its development, along with the JNA, which consistently played a self-consciously 'progressive' and 'experimental' role in Yugoslav housing design in general. Novi Beograd was a single vast, concentrated zone of elite housing, dedicated to the upper professional, military and government strata of Yugoslav socialist society (LeNormand 2014; Interview D and M Marusić, 7 July 2014; Mrduljaš and Kulić 2012: 36, 296-8; Blagojević 2012: 232-7).

In its orthogonal, linear layout, Novi Beograd, like Brasilia, presented a potent combination of 'motor age' grid planning with strong elements of stately symmetry - a spectacle-driven approach in distinct contrast to the more informal formulae of Soviet extensive urbanism, as seen especially in the Baltics in estates such as Lazdynai in Vilnius. Laid out on a north-west/south-east axis, its constituent elements were 'blocks' (blokovi), each 'blok' being much larger than a Brasilia superquadra, but similar in density (300 persons per hectare) (Mrduljaš and Kulić 2012: 163). The only equivalent to this in the Baltics was the original proposal for Tallinn's last and greatest mega-project, Lasnamäe, designed by Eestiprojekt in 
1970 and largely built in the 80 s: the original linear plan was centred around two parallel expressways.

In Novi Beograd, in a further expression of the 'participatory' and 'experimental' aspirations of Yugoslav socialism, public competitions were used for the urban design of each stage of development. As a result, the successive phases of Novi Beograd were stamped with an exaggeratedly individualistic character, more extreme than anything in the Baltics and fully up-to-date with contemporary 'conglomerate' or 'Brutalist' design trends in Western Europe. The years from 1966/7 onwards saw a veritable explosion of high density 'blok' projects in the central zone of Novi Beograd, mostly JNA-funded, highly variegated in architectural approach but featuring certain common elements, such as a Brasilia-like arrangement of open, columned ground floors including local shops, cafes and community facilities. (Mitrović 1975: 20-25; Mrduljaš and Kulić 2012: 297-8; interview D and M Marusić, 7 July 2014; Blagojević 2012: 232-40).

In 1977, the vertical culmination of Novi Beograd was built: Blok 33, or the 'Western Gate', matching Rudo on the East, designed by Mihajlo Mitrović and comprising two 32-storey office and residential towers crowned by a circular observation pavilion (140 m high) and linked by a high-level bridge, to form a 'gate' like image. By that stage, however, to the south-west, another, even more extreme phase of Novi Beograd was under construction, from 1971: blocks 61-64, comprising two parallel arrays of 40 stepped, clustered blocks of up to 20 storeys, all on a gigantic scale, filling four complete blokovi and containing 3,228 apartments - a concept hardly matched by anything in Moscow or Leningrad, let alone the Baltic states. The initial urban design concept was by architect Josip Svoboda, who claimed, rather quirkishly, to have been inspired by the traditional urban fabric of the Stradun, Dubrovnik's main pedestrian street. And right next door, to the south-east, was an equally extremist project: Blocks 44,45 and 70 , comprising a sea of nearly 90 tower blocks varying from 8 to 17 storeys, for higher income owner-occupation (Mrduljaš and Kulić 2012: 305-7; interviews D and M Marusić, 7 and 8 July 2014).

\subsection{Conclusion}

The flamboyant diversity of Novi Beograd vividly symbolised the pride and spectacle of Tito's Yugoslavia. All the more catastrophic, therefore, was the eventual decline and fall of the entire 'Yugoslav experiment', in the rampant inflation of the 1980s (peaking at $132 \%$ in 1986), which drained away the lending capital from enterprises' housing funds and foreshadowed the disintegration and civil war of the 1990s (Hegedüs et al. 2013: 280; Sillince 1990: 4, 22, 420).

And overall, the somewhat exaggerated policy fluctuations and spectacle-driven character ofmass housing in both Yugoslavia and Romania, however different from each other, both provide a vivid contrast with the Baltic republics, whose post-war housing may have lacked flamboyant fireworks, but instead, in the 1983 words of a 
group of Lithuanian architects, stressed 'the avoidance of grandeur and grandiosity, and a connection with nature'-in the process building up an enduring legacy for the post-socialist era (Drèmaitè 2017: 315).

\section{References}

Angermann K, Hilse T (2014) Altstadtplatten. BUV, Weimar

Architects' Journal (1967) Archit J 713-715. 22 March 1967

Architects' Journal (1967) Archit J 995-998. 26 April 1967

Balchin P (ed) (1996) Housing policy in Europe. Routledge, London

Bauakademie D (1968) Projekiert, Gebaut, Bewohnt. VEB Verlag für Bauwesen, Berlin

Bernhardt C (2005) Planning, urbanisation and urban growth in the socialist period. J Urban Hist 104-119. November 2005

Bernhardt C, Reif H (2009) Sozialistische Städte zwischen Herrschaft und Selbstbehauptung. Steiner, Stuttgart

Blagojević L (2012) The residence as a decisive factor. A\&U, XLVI 3-4:240

Branczik M (2012) Planning of standardised housing types in Hungary. A\&U 3-4:182-185

Branczik M, Keller M (2011) Korszerü lakás az óbudai kísérlet. Budapesti Történeti Múzeum, Budapest

Campbell JA, Hall JA (2015) The world of states. Bloomsbury, London

Ciolacu T (2015) Urban planning in Romania under the effect of Systematisation. In: DOCONF 2015 conference, October 2015. BME University, Budapest

Diener A (2012) Heimatgefühle im Pflasteblock. Frankfurter Allgemeine Zeitung, 16 August 2012

Donnison DV (1965) Housing policies in Eastern Europe. Trans Bartlett Soc 3:1964-1965

Drèmaitė M (2017) Baltic modernism: architecture and housing in Soviet Lithuania. DOM, Berlin

Dufaux F, Fourcault A (eds) (2004) Le monde des grands ensembles. Creaphis, Paris

ETH Studio Basel (2012) Belgrade, formal/informal. Scheidegger \& Spiess, Zürich

Ferkai A (2005) Housing estates. City Hall, Budapest

Fiedler T, Georgen M (2008) Die Geschichte der Deutschen. DTV, Munich

Friedrich J (2010) Neue Stadt in altem Gewand_-der Wiederaufbau Danzigs 1945-1960. Böhlau, Cologne

Gzell S (1995) Outline of postwar urban planning in Poland. Plan Hist 13(2):6-11

Hannemann C (1996) Die Platte. Vieweg, Braunschweig

Hannemann C (2004) Architecture as ideology: industrialisation of housing in the GDR. Humboldt Universität zu Berlin, Stadt-und Regionalsoziologie. Working papers 2A, January 2004

Hegedüs J, Lux M, Teller N (2013) Social housing in transition countries. Routledge, Abingdon

Hess DB, Hiob M (2014) Preservation by neglect in Soviet-era town planning in Tartu, Estonia. J Plan Hist 13(1):24-49

Honecker E (1981) Aus meinem Leben. Dietz Verlag, Berlin

Hryniewicz-Lamber G (2004) Late modern buildings in a historic town centre. In: DOCOMOMO-US, DOCOMOMO-international 2004 conference proceedings, New York, 2004, pp 275-281

Ionescu G, Derer P, Theodorescu D (1969) Arhitectura în România, perioada anilor 1944-1969. Editura Academiei Republicii Socialiste România, Bucharest

Jordan J (1967a) Industrialised building in Eastern Europe: German democratic republic. Arch J 677-680. 15 March 1967

Jordan J (1967b) Industrialised building in Eastern Europe: Czechoslovakia. Arch J 961-3. 19 April 1967

Kalm M (2002) Eesti 20. Sajandi arhitektuur. Sild, Tallinn 
Kalm M (2008) Is urban life in the countryside good? the central settlements of collective farms in the Estonian SSR. Kunstiteaduslikke Uurimusi 2008(4):61-87

Kedziorek A, Stanek $€$ (2012) Architecture as a pedagogical object. A\&U 46(3-4):252-262

Lankots E (2004) Classes in a classless society. Kunstiteaduslikke Uurimusi 2004(2):11-41

Lankots E, Söövati H (2008) ABC centres and identities of Mustamäe mikrorayons. Kunstiteaduslikke Uurimusi 4:88-116

Laurian R (1965) Urbanismul. Editura Tehnică, Bucharest

LeNormand B (2014). Designing Tito's capital — urban planning, modernism and socialism in Belgrade. University of Pittsburgh Press, Pittsburgh

Marin V (2011) Civil society and mass housing in post-communist Bucharest. In: DOCOMOMO conference, Edinburgh

Marmot AF (1981) Polish housing policies. Hous Rev

Metspalu M, Hess DB (2018) Revisiting the role of architects in planning large-scale housing in the USSR: the birth of socialist residential districts in Tallinn, Estonia, 1957-1979, Plan Perspect 33(3):335-361. https://doi.org/10.1080/02665433.2017.1348974

Meuser P (2015) Die Aesthetik der Platte. DOM, Berlin

Mitrović M (1975) Modern Belgrade architecture. Jugoslavija, Belgrade

Molnár V (2013) Building the state — architecture, politics and state formation in postwar central Europe. Routledge, Abingdon

Moravč́́ková H et al (2011) Bratislava Atlas Sidlisk. Slovart, Bratislava

Mrduljaš M, Kulić V (eds) (2012) Unfinished modernisations. UHA, Zagreb

Mumford E (2009) CIAM and the communist bloc. J Arch 14(2):239-241

Ojari T (2004) Floor space: the modernist residential housing ideology and Mustamäe. Kunstiteaduslikke Uurimusi 2004(2):42-70

Pugh E (2015) From national style to rationalised construction. J Soc Arch Hist 2015(3):87-108

Rietdorf W (1976) Neue Wohngebiete sozialistischer Länder. VEB Verlag für Bauwesen, Berlin

Sebestyén G (1965) Large panel buildings. Akadémiai Kiadó, Budapest

Sillince J (ed) (1990) Housing policies in East Europe and the Soviet Union. Routledge, Abingdon

Topfstedt T (1996) Die nachgeholte Moderne. In: Dolff-Bonekämper G, Kier H (eds) Städtebau und Staatsbau im 20. Jahrhundert. Munich 42-8

Tsenkova S (2009) Housing policy reforms in post-socialist Europe. Physica, Heidelberg

Urban F (2009) Neo-historical East Berlin. Ashgate, Farnham, 2009:5, 249, 259

Urban F (2011) Tower and slab. Routledge, Abingdon

Wynn M (ed) (1984) Housing in Europe. Croom Helm, London

Zahariade AM (2011) Arhitectura în proiectul comunist: România 1944-1989. Simetria, Bucharest Zarecor K (2011) Manufacturing a socialist modernity. Pittsburgh University Press, Pittsburgh

Zarecor KE (2017) What was so socialist about the socialist city? J Urban Hist 2017:9

Open Access This chapter is licensed under the terms of the Creative Commons Attribution 4.0 International License (http://creativecommons.org/licenses/by/4.0/), which permits use, sharing, adaptation, distribution and reproduction in any medium or format, as long as you give appropriate credit to the original author(s) and the source, provide a link to the Creative Commons license and indicate if changes were made.

The images or other third party material in this chapter are included in the chapter's Creative Commons license, unless indicated otherwise in a credit line to the material. If material is not included in the chapter's Creative Commons license and your intended use is not permitted by statutory regulation or exceeds the permitted use, you will need to obtain permission directly from the copyright holder. 